\title{
MYTHS ABOUT THE CHARRUA: TRUTH AND FICTION IN THE HISTORY OF THE INDIGENOUS PEOPLE OF URUGUAY
}

\author{
Timur V. Nelin \\ Volgograd State University, Volgograd, Russian Federation
}

\begin{abstract}
Introduction. The article is devoted to the Charrua, a little-known indigenous people of Uruguay. This people was exterminated in the first half of the $19^{\text {th }}$ century, giving rise to a number of myths about its history and culture. The author tries to find out, what information about the Charrua is based on facts, and what is a historical myth. The researcher considers such cases as the anthropological characteristics of the Charrua, the structure of the people, the history of its name, the case of the murder of Juan Diaz de Solis in 1516 and the history of the Natives taken to Paris in 1833. Methods and materials. The author uses the principles of historicism, objectivity, the general scientific, historical and genetic method. The data of linguistics, physical anthropology and ethnology are also involved. The article provides historiographical and source analysis related to the Charrua materials. Analysis. The physical appearance of the Charrua is related to the pampido anthropological type of the Chaco region. The tribe was heterogeneous and consisted of different groups. The name "Charrua" is of European origin and it is often used as a generic term for several related tribes. According to the sources, the Charrua were not involved in the murder of Juan Diaz de Solis. The latest historical studies of the Charrua taken to France show that there was not wonderful escaping of two members of this tribe. Results. The study shows that the most part of the existing historical and anthropological myths about the Charrua are completely or partially untrue.

Key words: Charrua, Native Americans, indigenous peoples, history of Uruguay, historiography, anthropology, historical myth.

Citation. Nelin T.V. Myths About the Charrua: Truth and Fiction in the History of the Indigenous People of Uruguay. Vestnik Volgogradskogo gosudarstvennogo universiteta. Seriya 4. Istoriya. Regionovedenie. Mezhdunarodnye otnosheniya [Science Journal of Volgograd State University. History. Area Studies. International Relations], 2020, vol. 25, no. 1, pp. 171-182. (in Russian). DOI: https://doi.org/10.15688/jvolsu4.2020.1.14
\end{abstract}

УДК 94(899)

ББК 63.3(7Уру)5

Дата поступления статьи: 28.01.2019

Дата принятия статьи: 25.09.2019

\section{МИФЫ О ЧАРРУА: ПРАВДА И ВЫМЫСЕЛ В ИСТОРИИ УРУГВАЙСКИХ ИНДЕЙЦЕВ}

\author{
Тимур Владимирович Нелин \\ Волгоградский государственный университет, г. Волгоград, Российская Федерация
}

\begin{abstract}
Аннотация. Введение. Статья посвящена чарруа, малоизученному племени уругвайских индейцев. Это племя было истреблено в первой половине XIX в., породив ряд мифов о своей истории и культуре в уругвайском обществе. Автор проверяет достоверность существующих ныне представлений о чарруа, опираясь на исторические и антропологические факты. Затрагиваются те аспекты истории и культуры народа, 을 отнсительно которых расходятся мнения ученых и публицистов, а именно: антропологические характерис๙ิ тики чарруа, структура народа, история названия племени, случай с убийством Хуана Диаса де Солиса в ю 1516 г. и история индейцев, увезенных в Париж в 1833 году. Методы и материаль. Ключевыми принципами исследования стали принципы историзма, объективности и научной достоверности. Помимо общенаучных методов в работе использовались историко-критический и историко-генетический методы. Были привлече胥 ны данные лингвистики, физической антропологии и этнологии. В статье приводится историографический и () источниковедческий анализ связанных с чарруа материалов. Анализ. Типичная внешность чарруа соответ-
\end{abstract}


ствовала антропологическому типу пампидов области Чако. Племя было неоднородным, состояло из разных групп, название «чарруа» имеет европейское происхождение и нередко употребляется как собирательное для ряда родственных племен, что вносит некоторую путаницу. Судя по данным источников, чарруа не причастны к убийству Х.Д. де Солиса. Согласно последним исследованиям истории увезенных во Францию чарруа, никакого чудесного спасения двух представителей этого племени не было. Результат. Исследование показало, что большинство сложившихся исторических и антропологических представлений о чарруа полностью или частично не соответствуют действительности.

Ключевые слова: чарруа, индейцы, коренные народы, история Уругвая, историография, антропология, исторический миф.

Цитирование. Нелин Т. В. Мифы о чарруа: правда и вымысел в истории уругвайских индейцев // Вестник Волгоградского государственного университета. Серия 4, История. Регионоведение. Международные отношения. -2020. - Т. 25, № 1.- C. 171-182. -DOI: https://doi.org/10.15688/jvolsu4.2020.1.14

Введение. История Уругвая неразрывно связана с индейцами чарруа. Это было не единственное племя, населявшее территорию страны, но так сложилось, что именно чарруа стали одним из символов Уругвая, символом непокоренности, мужества и свободолюбия. В честь этого племени названа и футбольная сборная страны.

Подобный символизм, если выражаться терминологией немецкого теоретика культурной памяти Яна Ассмана, способствует складыванию «коннективной структуры», то есть призван сплотить нацию, а также создать некие поведенческие императивы, соответствующие символическому образу. Естественно, что подобного рода символизм формируется через социально-политические мифы, которые далеко не всегда имеют историческое обоснование. История чарруа запутана настолько, что зачастую сложно понять, какая информация достоверна, а какая нет.

Считается, что индейцы чарруа были высокими, атлетически хорошо сложенными, говорили на ныне вымершем языке, о котором мало что известно. Племя было воинственным и яростно сопротивлялось колонизации. Именно они в 1516 г., как считается, убили, а согласно некоторым версиям и съели, испанского исследователя Хуана Диаса де Солиса.

Против чарруа сначала колониальными властями Испании, а потом и официальными властями Уругвая велась война на уничтожение. Это было частью так называемой политики по «борьбе с варварством». Народ был полностью истреблен в 1831 г. в результате резни у ручья Сальсипуэдес, которую устроил полковник Бернабе Ривера, племянник пер- вого президента Уругвая Фруктуосо Риверы. Последние захваченные в плен чарруа - шаман Сенакуа Сенаке, касик Ваймака Пиру, молодой воин Такуабе и ожидающая ребенка Гуюнуса - были вывезены в Париж в 1833 г., где демонстрировались публике как дикари Нового Света. Сенакуа Сенаке и Ваймака Пиру вскоре скончались, Гуюнуса умерла, не прожив и года после родов, а Такуабе сбежал с новорожденной девочкой, и их следы потерялись. Эта история широко известна и с разными вариациями представлена публике в интернет-пространстве. В Монтевидео есть соответствующий памятник - «Последние чарруа», как раз посвященный этим индейцам.

Такой образ чарруа - идеально сложенных физически, загадочных, непокоренных и с трагической историей - представляется несколько клишированным. С точки зрения коннективной функции мифа этот образ вполне приемлем. Однако с позиции научной достоверности здесь могут быть несостыковки. В этой связи цель данной статьи - уточнить, какая информация об индейцах чарруа и их истории является научно обоснованной, а какая не соответствует историческим фактам. Было решено обратить внимание на те вопросы, ответ на которые у исследователей племени неоднозначен, а именно: какие антропологические черты присущи чарруа, было ли племя однородным или состояло из племенных групп, откуда собственно возникло само название «чарруа», причастны ли они к убийству Хуана Диаса де Солиса и что доподлинно известно о судьбе «парижских» индейцев, в особенности Такуабе и младенца.

Методы и материалы. В данной статье не предполагается исследовать структу- 
ру уругвайских мифов о чарруа, их характер и коннективные функции. В этой связи подходы и методы, которые применяются для работы с мифами, например, те, которые в своей статье описали С.В. Бирюков и О.В. Омеличкин, в рамках настоящего исследования не подходят, поскольку не способствуют достижению заявленной цели [1, с. 187]. Ключевыми принципами исследования являются принципы историзма, объективности и научной достоверности, которые как раз и позволяют проверить, какие представления об индейцах являются верными, а какие мифологизированными конструктами или просто заблуждениями. Помимо общенаучных методов в работе используются историко-критический и историко-генетический методы.

Для уточнения родственных связей чарруа с другими племенами привлечены данные лингвистики, применяются элементы компаративного анализа, но не в смысле сравнения языковых единиц, как это делает сравнительная лингвистика. Исследованием языка чарруа уже занимались профессиональные лингвисты. Здесь же сравниваются результаты проведенных ими исследований о родстве языков с данными физической антропологии и этнологии.

Поскольку изучение истории народа неразрывно связано с теорией этноса, то надо отметить, что в рамках настоящего исследования индейцы чарруа рассматриваются с примордиалистской позиции, говоря несколько упрощенно, речь идет о «чистокровных» чарруа. Примордиалистский подход позволяет увидеть физические особенности так называемых типичных чарруа, то, что их отличало от соседних этносов внешне. Это важно ввиду того, что приведенная в литературе информация о внешности чарруа противоречива. Кроме того, сама история о последних четырех чарруа, увезенных в Париж, явно пронизана духом примордиализма, поскольку намекает на «чистокровность» этих индейцев.

Отечественная историография по чарруа представлена достаточно бедно. Как правило, это лишь информация справочного характера, по большей части историческая, в разного рода очерках по истории Уругвая [2, c. 201-203; 8, с. 506]. В энциклопедиях отдельные статьи по чарруа практически не встре- чаются. Единственное исключение - второе издание Большой советской энциклопедии. Там племя, правда, названо ча́рруа, с ударением на первый слог [11]. На этом, собственно, отечественные «исследования» племени и заканчиваются.

Что касается переводной литературы на русском языке, то чарруа упоминаются в книгах научно-популярного жанра. Буквально в двух словах об этом народе говорит чешский этнограф и писатель Милослав Стингл в своей известной книге «Индейцы без томагавков» $[10$, c. 289]. Немного информации о последних сражениях чарруа можно найти в работе уругвайского журналиста Эдуардо Галеано «Вскрытые вены Латинской Америки» [4, с. 81]. Чуть подробнее об истории племени рассказывает гватемальский писатель Мануэль Галич [5, c. 394-397]. Но все равно эти авторы дают лишь краткую информацию о чарруа.

Современное русскоязычное пространство Интернета не намного богаче фактическим материалом. В действительности русскоязычные интернет-статьи представляют собой переводы или пересказы англоязычных или испаноязычных статей, притом часто с устоявшимися мифами. Все они по сути однотипные и написаны в публицистическом стиле [7; 9].

Зарубежная историография гораздо шире. Есть, конечно, и материалы справочного характера, и упоминания о чарруа в контексте истории Уругвая, но есть и работы, непосредственно посвященные этому племени.

Одним из первых исследователей чарруа стал уругвайский антрополог Хосе Энрикес Фигуэйра. Стараясь развить идею уникальности уругвайской нации, подчеркнуть отличие уругвайцев от испанских конкистадоров, он апеллировал к несгибаемому духу коренных жителей страны. Намеренно или нет, но благодаря стараниям Х.Э. Фигуэйры был создан образ чарруа как непримиримых противников конкисты, воинственного и кровожадного племени. Он популяризировал идею о том, что чарруа в 1516 г. убили испанского исследователя Хуана Диаса де Солиса [25, р. 19]. Эта версия гибели испанского путешественника распространена достаточно широко.

Историю и останки увезенных во Францию «последних чарруа» изучал в начале XX в. французский этнограф и директор Музея че- 
ловека в Париже Поль Риве. Он тщательнейшим образом исследовал все обстоятельства пребывания чарруа в Европе. Благодаря его стараниям мы знаем, что стало с этими индейцами. Однако П. Риве не раскрывает историю сбежавшего с младенцем Такуабе. Тем не менее именно его исследование, впервые опубликованное в 1930 г. под названием «Последние чарруа», легло в основу столь популярного мифа [35].

Другой известный ученый, который писал о коренных уругвайцах, - аргентинский археолог и этнограф Антонио Серрано. Его историко-этнографический очерк о чарруа вошел в первый том широко известного Справочника по индейцам Южной Америки [42]. Этот очерк по-прежнему считается одним из лучших по чарруа.

Уругвайский археолог Родольфо Марука Соса в работе «Народ чарруа» обобщил всю имеющуюся на тот момент информацию по чарруа - историческую, археологическую, этнографическую и др. Это сделало его исследование поистине ценным [32].

Развенчанием мифа о кровожадности чарруа занимался уругвайский антрополог Серафин Кордеро. Он описывал племя как достаточно дружелюбное, отмечал высокие морально-этические качества индейцев, их радушие в отношении белых путешественников. В то же время упоминал и о свободолюбии чарруа, их неприятии попыток захватить свои земли $[24$, р. 206]. Такой образ чарруа хоть и отличался от образа, нарисованного Х.Э. Фигуэйрой, но был призван выполнять ту же функцию - обосновывать исключительность уругвайской нации, поэтому тоже должен восприниматься критически.

Все эти работы по чарруа можно назвать классическими. Племя ушло в историю, и найти про него какую-либо новую информацию сейчас совсем непросто. Из современных работ, посвященных этому индейскому народу, следует назвать труды уругвайского антрополога Даниеля Видарта, бразильского профессора Итала Ирен Басиль Бекера, аргентинского историка и этнографа Хуана Хосе Росси, уругвайского историка Диего Бракко и др. [18; $20 ; 21 ; 22 ; 37 ; 44 ; 46]$. Отдельно стоит упомянуть работы французского антрополога Дарио Арсе Асеньо, который продолжил расследова- ние П. Риве относительно «парижских» индейцев, а также свел воедино самые последние научные данные о народе чарруа [13; 14].

Кроме того, следует сказать о лингвистическом направлении исследования чарруа. Язык этого племени является мертвым и плохо задокументированным. Сохранилось примерно 70 зафиксированных слов и система числительных. Практически ничего не известно о грамматике. Скудность фактических данных привела к формированию нескольких теорий относительно семейной и групповой принадлежности языка чарруа. Высказывались предположения, что чарруа может быть языком-изолятом [40, s. 260], делались попытки увязать его с группой каинганг [42, p. 192], гуайкуру [27, p. 207, 238; 43, p. 94] и т. д. Конечно, здесь надо принимать во внимание то обстоятельство, что лингвисты и антропологи предлагают свои собственные классификации индейских языков, своеобразные названия семей и групп. Это вносит некоторую путаницу. Поэтому, чтобы сказать, к какой языковой семье и какой группе относится чарруа, нужно, как минимум, встать на сторону одного из ученых и согласиться с его оригинальной классификацией.

В целом про историю изучения языка чарруа неплохо написал уругвайский лингвист Хуан Хустино да Роса в своей статье «Историография лингвистики Ла-Платы: коренные языки Восточной полосы» [36].

Источников по истории и культуре чарруа сохранилось относительно немного. Есть археологические материалы, которые позволяют дать ответ на ряд вопросов, например, о физических данных чарруа, ранней культуре народа, миграциях и т. д. В целом археология племени была хорошо изучена уже к середине XX в. и отражена в историографии, поэтому нет смысла останавливаться на этом типе источников подробно.

Из письменных источников по чарруа ключевым видом являются материалы личного происхождения - свидетельства очевидцев того периода, когда племя еще не было истреблено. Эти источники можно условно разделить на три группы, исходя из хронологического принципа.

Первая группа - записки путешественников XVI, отчасти XVII веков. Это, напри- 
мер, заметки андалузского исследователя Диего Гарсии де Могера 1526-1527 годов. Собственно в его работе впервые упомянуто племя чарруа [34, p. 45]. Второе упоминание чарруа (zechuruass) приходится на 1536 г. и связано с именем немца Ульриха Шмидля, который был летописцем экспедиции известного конкистадора Педро де Мендосы [39, p. 146]. Упоминание этого народа можно также найти в эпической поэме «Аргентина и завоевание Ла-Платы», которую испанский священник Мартин дель Барко Сентенера написал по результатам своих путевых заметок 1573 года [17, p. 4]. Это лишь некоторые примеры ранних записок путешественников. В целом каких-то серьезных этнографических наблюдений по чарруа в этих источниках нет.

Вторая группа материалов личного происхождения - свидетельства иезуитских миссионеров конца XVII - XVIII в., которые описывали язык, быт, внешность, основные этапы истории своих подопечных. В основном это были племена гуарани, но информация по чарруа также встречается. К такому роду источников относятся записи французского священника-иезуита Николаса дел Течо ${ }^{1}$, немецких миссионеров Энтони Сеппа и Энтони Бёме, испанского аббата Лоренцо Эрваса [28, р. 193-197; 41; 45] и т. д.

Третья группа материалов личного происхождения - заметки ученых-путешественников, которые непосредственно общались с представителями племени и опубликовали результаты своих исследований в начале XIX века. Прежде всего, это испанский путешественник Феликс де Азара и французский натуралист Альсид Дессалин д’Орбиньи [16, p. 6-35; 33, p. 83-92]. Их работы дают ценную информацию об истории и культуре поздних чарруа.

К сожалению, все материалы личного происхождения страдают от недостатка профессионального этнографического подхода. Кроме того, очень не хватает визуального материала по культуре чарруа. Но поскольку племя уже исчезло, восполнить этот пробел не представляется возможным.

Анализ. Большинство найденных археологами артефактов подтверждает принадлежность чарруа к культуре, сходной с патагонской: идентичные каменные орудия труда, круглые и звездчатые каменные болы, керамические изделия с резными рисунками и т. д. [42, р. 191]. Чего-то принципиально нового, опровергающего уже сложившееся представление о ранней культуре племени, до сих пор не найдено. Археологические данные подтверждают также и антропологическую близость чарруа к коренным жителям Патагонии. Исходя из терминологии немецкого антрополога Эгона фон Эйкштедта, можно сказать, что чарруа относятся к типу патагонидов, или в терминологии аргентинского антрополога Хосе Имбеллони - пампидов.

Примечательно, что Д. Видарт, основываясь на данных физической антропологии, ставит под сомнение принадлежность Ваймака Пиру к чарруа, поскольку рост касика, как указывает антрополог, 1,55 м, в то время как для чарруа средний рост должен быть примерно 1,8 м [29]. Сомнение Д. Видарта касается не только Ваймака Пиру, но и Такуабе и Гуюнусы, которые были крещены в церкви Пайсанду. Антрополог указывает на то обстоятельство, что чарруа, в отличие от их соседей гуарани, противились принятию христианства. На этом основании он делает предположение, что как минимум трое из четырех увезенных в Париж индейцев были не чарруа, а гуарани [29].

Если доводы Д. Видарта относительно принадлежности Такуабе и Гуюнусы имеют историческое основание и с ними в чем-то можно согласиться, то заметка о Ваймаке Пиру, основанные на данных физической антропологии, могут подвергнуться критике. Вопервых, согласно исследованиям останков Ваймака Пиру, его рост составлял 1,62 м. Метохондриальное ДНК касика относится к америндскому гаплотипу $\mathrm{C}$, сродни тем останкам, что были найдены при раскопках ранних стоянок в Уругвае [38, p. 4, 5]. Так что по материнской линии он вполне принадлежит к чарруа. Во-вторых, как указывает Х. Имбеллони, рост мужчин пампидов в области Чако 1,6-1,7 м, в Патагонии - 1,73-1,81 м [6, с. 23]. Средний рост мужчины чарруа, таким образом, не обязательно должен приближаться к отметке 1,8 м. Это подтверждают и письменные источники. Например, А.Д. д’Орбиньи, описывая чарруа, которых он наблюдал в 1829 г. недалеко от Монтевидео, указывает на 
то, что их средний рост составлял 1,65 м для женщин и 1,68 м для мужчин. Он также отмечал, что у них широкие лица, выдающиеся скулы, медная кожа и прямые жесткие волосы [33, p. 86].

Заметки А.Д. д’Орбиньи также опровергают заявление известного французского антрополога Поля Броки о том, что кожа чарруа так же черна, как у жителей Эфиопии [3].

О племенной структуре чарруа можно судить по данным, приведенным иезуитскими миссионерами. Л. Эрвас, в частности, указывает на то, что чарруа - лишь одно из пяти родственных племен наряду с гуэноа, яро, минуанами и боанами ${ }^{2}$. Он также говорит, что общее название народа - гуэноа, а не чарpya $[28$, p. 197]. Эта версия, однако, не является общепризнанной. Есть мнение, что гуэноа и минуаны - это не два разных племени, а одно, просто под разными названиями. А. Серрано, например, говорит, что испанские миссионеры называли это племя минуанами, и именно под этим названием оно стало известно в бразильской литературе [42, p. 191]. Американский антрополог Сэмюэл Лотроп полагает, что гуэноа и минуаны были одним народом, при этом он апеллирует к мнению испанского иезуита-миссионера Педро Лозано, которого считает наиболее авторитетным в этом вопросе [30, p. 183]. Д. Бракко также признает, что гуэноа и минуаны - это разные названия одного племени [22, p. 33].

Как бы то ни было, со временем общий состав народа изменился. Яро и боаны были маленькими племенами, и, несмотря на родственные связи, чарруа их истребили. Минуаны-гуэноа в 1730 г. объединились с чарруа в тесный союз и по сути стали одной племенной ветвью [19, s. 402; 30, p. 184, 185]. Кроме того, и у минуанов-гуэноа, и собственно у чарруа были еще свои деления на группы. Известно, что у первых в XVII в. выделялась племенная группа клоя (Cloya), а у вторых - группы гуаянтиран, баломар и негегиан (Guayantiran, Balomar, Negueguian), проживавшие на территории аргентинской провинции Энтре-Риос в XVIII веке [42, p. 192].

Исходя из антропологических и лингвистических данных, еще одним родственным чарруа народом можно считать уругвайское племя чана. Хотя в культурном плане чана подверглись влиянию гуарани, их отличал нетипичный для гуарани высокий рост, характерный для пампидов, и язык, близкородственный чарруа. Эту языковую связь родственных чарруа племен лингвисты считают вполне доказанной [27; 31, p. 61; 42, p. 192; 47].

В данном же контексте интерес к чана вызван тем, что в 2005 г. в Ногое (Энтре-Риос, Аргентина) объявился пожилой мужчина, который, как утверждали журналисты, знал около 250 слов и фраз на языке чана. Это заинтересовало ученых, и с предполагаемым информантом стал работать аргентинский лингвист Хосе Педро Виегас Баррос [26]. В результате своего исследования Х.П. Виегас Баррос написал несколько статей по языку чана. При этом ученый затронул и тему взаимосвязи языков чана и чарруа [47]. Такого рода находку можно считать уникальным событием в исследовании давно вымершего народа.

Говоря о языке чарруа и чана, нужно упомянуть одно обстоятельство, которое вводит в заблуждение исследователей и журналистов. Дело в том, что в Уругвае, помимо чарруаговорящих народов, проживали еще и племена гуарани. Элементы их языка нередко отражены в топонимике страны и некоторых именах собственных. Кроме того, как отмечал иезуитский миссионер Хосе Кардиэль еще в середине XVIII в., почти все взрослые чарруа знали язык гуарани и использовали его для межплеменного общения и общения с миссионерами [36, p. 142]. Вероятно, это обстоятельство и ввело в заблуждение российского журналиста С.Б. Брилёва, который причисляет чарруа к «великой индейской нации гуарани», хотя очевидно, что это не так [2, с. 201].

Поскольку тема коснулась языка, необходимо внести ясность в вопрос об этимологии слова «чарруа», тем более что, по мнению Л. Эрваса, народ правильнее называть гуэноа [28, p. 197]. Известно, что «чарруа»это не самоназвание племени. Самоназвание как раз неизвестно, и, к сожалению, вряд ли когда-нибудь ученые его узнают. В 2001 г. Д. Видарт провел этимологический анализ и выяснил, что «чарруа» - это галисийское слово, означающее маскарадные маски из дерева. Происхождение этих масок, как указывает антрополог, уходит в доисторические времена, где они, вероятно, использовались на 
фестивалях типа карнавала. В Галисии эти маски называли «чарруа», их украшали и ярко разрисовывали, придавая вид агрессивных гримас. Согласно логике Д. Видарта, когда европейцы достигли берегов Ла-Платы, они встретили индейцев в красочных нарядах, с ярко раскрашенными лицами, татуировками и пирсингом, что дало повод испанским морякам вспомнить о галисийских праздникахмаскарадах с их раскрашенными маскамичарруа [23].

К этому можно добавить, что, согласно А. Серрано, первые путешественники XVI в. использовали название чарруа только в отношении групп, которые жили на побережье и периодически кочевали вглубь страны. Очевидно, со временем все схожие с ними по культуре и языку индейские общины стали называться чарруа [42, p. 191]. Судя по всему, отсюда и возникло общее для родственных народов имя.

Поскольку категории «кровожадность» и «воинственность», которые нередко употребляют в отношении чарруа, абстрактны, нет необходимости выяснять, насколько они соответствуют характеру племени. Здесь же важно разобраться с конкретной претензией к этому народу - убийством Хауна Диаса де Солиса. Версия убийства испанского путешественника индейцами чарруа фигурировала в литературе еще до широко известного труда Х.Э. Фигуэйры. Так, ее можно встретить в «Путешествии по Южной Америке» Ф. де Азары $[16$, p. 6]. Хотя очевидно, что Ф. де Азара сам заимствовал эту версию из более ранних произведений, например, в «Описании истории Парагвая и ЛаПлаты», опубликованной через 26 лет после смерти Ф. де Азары, он ссылается на П. Лозано и некоторых других авторов [15, p. 3-4]. Но очевидно, что и П. Лозано также не мог быть свидетелем тех событий. В любом случае, Ф. де Азара подвергает критике высказанное предыдущими авторами мнение, что чарруа съели испанского путешественника. При этом, однако, не сомневается, что именно они его убили [15, p. 3-4]. Чести ради нужно заметить, что антропологи так и не нашли следов антропофагии в культуре чарруа, в отличие от соседних с ними племен гуарани, которые в те времена отдельными группами проживали в районе Ла-Платы [30, p. 179]. Так что, отрицая каннибализм у чарруа, Ф. де Азара был прав.

Вообще, наиболее близкое по хронологии упоминание о смерти Х.Д. де Солиса можно найти у итальянского историка Пьетро Мартире д’Ангьеры, который был на службе у Испанской короны. В «Декадах о Новом Свете», в книге X, написанной в том же 1516 г., когда погиб Х.Д. де Солис, П. д’Ангьера хоть и не говорит прямо об убийстве, но упоминает о печальной участи испанского путешественника после его встречи с «карибскими людоедами» [12, р. 292]. Здесь можно видеть явный намек на одно из амазонских племен, к которым в принципе относятся некоторые группы гаурани.

Теперь нужно прояснить ситуацию с «последними чарруа», вывезенными в Париж в 1833 году. Прежде всего надо сказать, что эти индейцы не были последними представителями племени. Это исторический миф. Доподлинно известно, и, собственно, на счет этого научные дебаты не ведутся, что разрозненные группы чарруа продолжали существовать. Собственно полковник Бернабе Ривера так и погиб от их рук [24, p. 228]. Некоторые из них впоследствии бежали на территорию современной Аргентины и Парагвая, кто-то переселился на юг Бразилии. Кроме того, потомки чарруа, метисы, продолжали жить и на территории самого Уругвая. В основном они занимались скотоводством, были частью субэтнической группы гаучо. Так что последними чарруа правильнее было бы считать не увезенных в Европу индейцев, а тех, кто остался, растворился со временем в других этносах и потерял свою идентичность.

Представленный в Монтевидео памятник «Последние чарруа» также не точен с точки зрения исторической достоверности. На нем показаны четыре взрослых чарруа, Гуюнуса при этом держит новорожденную девочку на руках. Однако известно, что девочка родилась уже после смерти Сенакуа Сенаке и Ваймака Пиру. Первый умер 26 июля 1833 г., второй - 13 сентября. Девочка родилась 20 сентября того же года $[14$, p. 59, 60, 63]. Гуюнуса скончалась в Лионе 23 июля 1834 г. от туберкулеза. В Лионе индейцы оказались после того как туда сбежал Франсуа де Кюрель, непосредственный организатор выстав- 
ки чарруа в Париже. Бегство было вызвано тем обстоятельством, что парижане потребовали от Ф. де Кюреля вернуть пленников на Родину [14, p. 64]. Как показывают последние исследования, никакого таинственного исчезновения Такуабе и новорожденной девочки не было. Маленькая Каролина Такуабе умерла в Лионе в ночь на 29 августа 1834 года. Причина смерти девочки не указывается, но есть предположение, что она могла заразиться туберкулезом от матери [14, p. 67-68]. Что доподлинно стало с Такуабе, пока так и не известно. Учитывая описанные современниками черты его характера и открытость к новшествам, предполагается, что если он не заразился туберкулезом, то мог частично адаптироваться к новым условиям и быть, к примеру, разнорабочим в одном из магазинчиков Лиона.

Результаты. Как можно видеть, большая часть сложившихся представлений о чарруа не соответствует действительности. Индейцы не были высокими в современном понимании этого слова. В структурном плане племя не отличалось однородностью и состояло из родственных групп, а название «чарруа» по большей части употребляется сейчас как собирательное. Притом само название, судя по всему, не индейского, а европейского происхождения. Были чарруа кровожадными или нет - вопрос философский, но есть все основания полагать, что они не причастны к убийству испанского путешественника и исследователя Хуана Диаса де Солиса. Увезенных во Францию в 1833 г. индейцев нельзя считать последними представителями племени. Никакого бегства Такуабе с младенцем не было. История этих индейцев трагична и заканчивается в Лионе.

Мода на «индейское прошлое» и определенные политические процессы как в самом Уругвае, так и в регионе вообще накладывают отпечаток на трактовку научных достижений. Несмотря на работы ученых, исторические мифы не преодолеваются, но продолжают существовать. В этих условиях можно ожидать и дальнейшего замалчивания или даже намеренного искажения достоверной информации о чарруа. Тем не менее, несмотря на все эти сложности, можно уверенно сказать, что история исчезнувшего племени все еще продолжается.

\section{ПРИМЕЧАНИЯ}

${ }^{1}$ Николас дел Течо (Nicolás Del Techo) - это испанский вариант его французского имени Nicolás $\mathrm{Du}$ Toict. Именно под испанским, а не французским вариантом своего имени он вошел в историю.

${ }_{2}$ Во втором томе энциклопедического справочника по Латинской Америке названия этих групп приведены с опечатками: гекоа, яро, минцане, боане [8, с. 506]. В любом случае вопрос, как правильно писать эти названия в русской транскрипции, остается открытым. Здесь надо отметить, что в западной историографии нет единого варианта написания. Например, А. Серрано, ссылаясь на данные иезуитских миссий, называет их yaró, güenoa, bohané, minuané [42, p. 191]. У Д. Бракко они соответственно фигурируют как уаro, guеnoa, bohan, minuán [20] и т. д. В целом же, учитывая наиболее распространенные варианты написания и правила русского языка для транскрипции, правильнее будет называть эти группы: яро, гуэноа, боаны, минуаны.

\section{СПИСОК ЛИТЕРАТУРЫ}

1. Бирюков, С. В. Современные мифы Запада о России / С. В. Бирюков, О. В. Омеличкин // Вестник Волгоградского государственного университета. Серия 4, История. Регионоведение. Международные отношения. - 2018. - Т. 23, № 6. - С. 185196. -DOI: https://doi.org/10.15688/jvolsu4.2018.6.15.

2. Брилёв, С. Б. Забытые союзники во Второй мировой войне / С. Б. Брилёв. - М. : ОЛМА Медиа Групп, 2013. $-712 \mathrm{c}$.

3. Брока, П. Человечество - один вид или несколько? // Правда-TV.ru. - 2010. - 22 апр. - Электрон. текстовые дан. - Режим доступа: http://www.pravdatv.ru/2010/04/22/3626 (дата обращения: 21.01.2019). Загл. с экрана.

4. Галеано, Э. Вскрытые вены Латинской Америки / Э. Галеано. - М. : Прогресс, 1986. - 398 с.

5. Галич, М. История доколумбовых цивилизаций / М. Галич. - М. : Мысль, 1990. - 407 с.

6. Зубов, А. А. Биолого-антропологическая характеристика коренного доевропейского населения Америки / А. А. Зубов // Население Нового Света: проблемы формирования и социокультурного развития : сб. ст. / отв. ред. А. А. Истомин. М. : ИЭА РАН, 1999. - С. 11-66.

7. Кержаков, Б. «Доподлинные люди» чарруа / Б. Кержаков // Необычная история. - 2014. 28 янв. Электрон. текстовые дан. - Режим доступа: http://nethistory.su/blog/43208728468/ «Dopodlinnyie-lyudi»-charrua (дата обращения: 21.01.2019). - Загл. с экрана. 
8. Колобашкин, Н. Ф. Уругвай: исторический очерк / Н. Ф. Колобашкин // Латинская Америка: Энциклопедический справочник. В 2 т. Т. 2 / отв. ред. В. В. Вольский. - М. : Советская энциклопедия, 1982. - С. 506-508.

9. Проклятие последнего шамана чарруа // Repin.info. - 2009. - 20 авг. - Электрон. текстовые дан. - Режим доступа: http://repin.info/taynyeznaniya/proklyatie-poslednego-shamana-charrua (дата обращения: 21.01.2019). - Загл. с экрана.

10. Стингл, М. Индейцы без томагавков / М. Стингл. - М. : Прогресс, 1984. - 454 с.

11. Чарруа // Большая советская энциклопедия. В 51 т. Т. 47 / гл. ред. Б. А. Введенский. -2-е изд. М. : БСЭ, 1957.-С. 53.

12. Anghiera, P. M. d'. Décadas del nuevo mundo / P. M. d'Anghiera. - Buenos Aires : MAXTOR, 2012. $675 \mathrm{p}$.

13. Arce Asenjo, D. L'Uruguay, une nation d'extrême-occident au miroir de son histoire indienne / D. Arce Asenjo. - Paris : L'Harmattan, 2018. - 394 p.

14. Arce Asenjo, D. Nuevos datos sobre el destino de Tacuavé y de la hija de Micaela Guyunusa / D. Arce Asenjo // Anuario de Antropologia Social y Cultural en Uruguay 2007 / ed. S. Romero Gorski. - Montevideo : Universidad de la República, Facultad de Humanidades y Ciencias de la Educación, 2007. - P. 51-71. Electronic text data. - Mode of access: http://www. academia.edu/1105620/Nuevos_datos_sobre_el_ destino_de_Tacuavé_y_la_hija_de_Guyunusa (date of access: 22.01.2019). - Title from screen.

15. Azara, F. de. Descripcion e historia del Paraguay y el Rio de la Plata. En 2 vols. Vol. 2 / F. de Azara. - Madrid : Imprenta de Sanchiz, 1847. - 286 p.Electronic text data. - Mode of access: https://books. google.ru/books?id=L3g1AAAAIAAJ\&dq (date of access: 23.01.2019). - Title from screen.

16. Azara, F. de. Voyage dans l'Amérique méridionale. En 4 vols. Vol. 2 / F. de Azara. - Paris : Dentu, 1809. - 562 p. - Electronic text data. - Mode of access: https://books.google.ru/books?id=zANCAA AAcAAJ\&dq (date of access: 23.01.2019). - Title from screen.

17. Barco Centenera, M. del. Argentina y conquista del Rio de la Plata, con otros acaecimientos de los reynos del Peru, Tucuman, y estado del Brasil / M. del Barco Centenera. - Lisboa : Pedro Crasbeeck, 1602. -460 p. - Electronic text data. - Mode of access: https://books.google.ru/books?id=1tJVAAAAc AAJ\&dq (date of access: 23.01.2019). - Title from screen.

18. Becker, I. I. B. Os índios Charrua e Minuano na antiga banda oriental do Uruguai / I. I. B. Becker. - São Leopoldo, RS, Brasil : Editora Unisinos, 2002. - 248 p.

19. Bertuch, F. J. Allgemeine geographische Ephemeriden / F. J. Bertuch. - Weimar : Verlage des
landes-Industrie comptoirs, 1809. - 530 s. - Electronic text data. - Mode of access: https://books.google.de/ books?id=Ad4BAAAAYAAJ\&dq (date of access: 23.01.2019). - Title from screen.

20. Bracco, D. Charrúas, Guenoas y Guaraníes: Interacción y Destruccíon: Indígenas en el Río de la Plata / D. Bracco. - Montevideo : Linardi y Risso, 2004. $-398 \mathrm{p}$.

21. Bracco, D. Con las armas en la mano: Charrúas, Guenoa-Minuanos y Guaraníes / D. Bracco. Montevideo : Planeta, 2013. - 224 p.

22. Bracco, D. Los guenoa minuanos misioneros / D. Bracco // Memoria Americana. Cuadernos de Etnohistoria. - 2016. - № 24-1. - P. 33-54. - Electronic text data. - Mode of access: http://www.scielo.org.ar/ $\mathrm{pdf} / \mathrm{memoam} / \mathrm{n} 24-1 / \mathrm{n} 24-1 \mathrm{a} 03$.pdf (date of access: 20.01.2019). - Title from screen.

23. Charrúa // Castellano - La Página del Idioma Español. - Electronic text data. - Mode of access: http:// www.elcastellano.org/palabra/charrúa (date of access: 22.01.2019). - Title from screen.

24. Cordero, S. Los charrúas: síntesis etnográfica y arqueológica del Uruguay/S. Cordero. - Montevideo : Editorial "Mentor", 1960. -322 p.

25. Figueira, J. H. Los primitivos habitantes del Uruguay/ J. H. Figueira. - Montevideo : Dornaleche y Reyes, 1892. -44 p.

26. Fiorotto, D. T. Investigan los orígenes de una extraña lengua indígena / D. T. Fiorotto // La Nación. 2005, July 1. - Electronic text data. - Mode of access: https://www.lanacion.com.ar/717592-investigan-losorigenes-de-una-extrana-lengua-indigena (date of access: 22.01.2019). - Title from screen.

27. Greenberg, J. H. Language in the Americas / J. H. Greenberg. - Stanford : Stanford University Press, 1987. -438 p.

28. Hervás, L. Catálogo de las lenguas de las naciones conocidas, y numeracion, division, y clases de estas segun la diversidad de sus idiomas y dialectos. En 6 vols. Vol. 1 / L. Hervás. - Madrid : En la imprenta de la Administracion del Real Arbitrio de Beneficencia, 1800. - 396 p. - Electronic text data. - Mode of access: https://books.google.ru/books?id= 8vA3GAo3S8kC\&hl (date of access: 23.01.2019). - Title from screen.

29. Los charrúas que no son charrúas // Taringa! 21.10.2015. - Electronic text data. - Mode of access: https://www.taringa.net/post/info/19024456/Loscharruas-que-no-son-charruas.html (date of access: 22.01.2019). - Title from screen.

30. Lothrop, S. K. Indians of the Paraná Delta and La Plata Littoral / S. K. Lothrop // Handbook of South American Indians. In 7 vols. Vol. 1. The Marginal Tribes / ed. J. H. Steward. - Washington, D. C. : Government Printing Office, 1946. - P. 177-190.

31. Loukotka, Č. Classification of South American

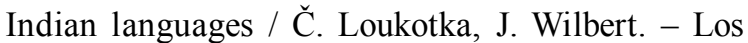


Angeles : Latin American Studies Center, University of California, 1968. - $453 \mathrm{p}$.

32. Maruca Sosa, R. La nación charrúa/ R. Maruca Sosa. - Montevideo : Editorial "Letras", 1957. - 316 p.

33. Orbigny, A. D. d'. L'homme americain (de l'Amériqueméridionale). En 2 vols. Vol. 2/A.D. d'Orbigny. Paris : Pitois-Levrault et C., 1839. - 372 p. - Electronic text data. - Mode of access: https://books. google.ru/books? id=CAOAAAAQAAJ\&hl (date of access: 23.01.2019). Title from screen.

34. Relación é derrotero de Diego Garcia que salió de la Coruna en 15 de enero de 1526, en el Mar Océano, é llegó en 27 al Rio Paraná, donde navegó muchas leguas tierra adentro la armada de Sebastian Caboto, etc., 1527 / D. G. de Moguer // Colección de Documentos inéditos para la historia de Chile: desde el Viaje de Magallanes hasta la Batalla de Maipo: 1518-1818. En 30 vols. Vol. 3 / Col. y publ. por J. T. Medina. - Santiago de Chile : Imprenta Ercilla, 1889. - P. 40-48. - Electronic text data. - Mode of access: https://archive.org/details/ raha_103066/page/n5 (date of access: 23.01.2019).Title from screen.

35. Rivet, P. Los últimos charrúas / P. Rivet. Montevideo : Ediciones de la Plaza, 1996. -88 p.

36. Rosa, J. J. da. Historiografía lingüística del Río de la Plata: las lenguas indígenas de la Banda Oriental / J. J. da Rosa // Boletín de Filología. - 2013. Vol. 48, № 2. - P. 131-171. - Electronic text data. Mode of access: https://scielo.conicyt.cl/pdf/bfilol/ v48n2/art_07.pdf(date of access: 20.01.2019). - Title from screen.

37. Rossi, J. J. Los charrúas / J. J. Rossi. - Buenos Aires : Galerna; Búsqueda de Ayllu, 2002. - 126 p.

38. Sans, M. The "last Charrúa Indian"(Uruguay): analysis of the remains of Chief Vaimaca Perú / M. Sans, G. Figueiro, C. Sanguinetti [et al.] // Nature Precedings. - 2010, May 4. - 14 p. - Electronic text data. - Mode of access: http://precedings.nature.com/ documents/4415/version/1/files/npre20104415-1.pdf (date of access: 22.01.2019). - Title from screen.

39. Schmidel, U. Viaje al Río de la Plata (15341554) / U. Schmidel. - Buenos Aires : Cabaut y Cia, 1903. - 499 p. - Electronic text data. - Mode of access: http://www.cervantesvirtual.com/obra-visor/viaje-alrio-de-la-plata-1534-1554/html/ (date of access: 23.01.2019). - Title from screen.

40. Schmidt, W. Die Sprachfamilien und Sprachenkreise der Erde / W. Schmidt. - Heildelberg : H. Buske, 1926. - $595 \mathrm{~s}$.

41. Sepp, A. An Account of a Voyage from Spain to Paraquaria. Translated from the High Dutch Original, Printed at Nurenberg, 1697 / A. Sepp, A. Behme // A Collection of Voyages and Travels, Some Now First Printed from Original Manuscripts, Others Now First Published in English. In 6 Vols. Vol. 4 / comp. by A. Churchill, Jh. Churchill. - London : Assignment from
Messrs. Churchill, 1732. - P. 596-622. - Electronic text data. - Mode of access: https://books.google.ru/ books?id=jORWAAAAcAAJ\&dq (date of access: 23.01.2019). - Title from screen.

42. Serrano,A. The Charrua/A. Serrano//Handbook of South American Indians. Vol. 1. - Washington, D. C., 1946.-P. 191-196.

43. Sušnik, B. Los aborígenes del Paraguay: Etnología del Chaco Boreal y su perifería, siglos XVI y XVII / B. Sušnik. - Asunción : Museo Etnográfico Andrés Barbero, 1978. - 154 p.

44. Szilágyi Chebi, M. E. Los charrúas en la memoria nacional de Uruguay / M. E. Szilágyi Chebi // Acta Hispanica. - 2015. - Vol. 20. - P. 105-120. Electronic text data. - Mode of access: https://www. academia.edu/23457388/Los_charrúas_en_la_ memoria_nacional_de_Uruguay (date of access: 28.11.2019). - Title from screen.

45. Techo, N. del. Historia provinciae Paraquariae Societatis Jesv. / N. del. Techo. - Leodii : Ex officina typog. J. M. Hovii, 1673. - 390 p. - Electronic text data. - Mode of access: https://books.google.ru/ books?id=76ZFAAAAcAAJ\&hl (date of access: 23.01.2019). - Title from screen.

46. Vidart, D. El mundo de los charrúas / D. Vidart. Montevideo : Ediciones de la Banda Oriental, 1996. $139 \mathrm{p}$.

47. Viegas Barros, J. P. Misia jalaná: Una frase Charrúa a la luz de los nuevos datos de la lengua Chaná / J. P. Viegas Barros // Cuadernos de Etnolingüística. Serie Notas. - 2009 (nov.). - № 1. - 3 p. - Electronic text data. - Mode of access: http://etnolinguistica. wdfiles.com/local—files/nota:1/cadernos_notas_n1. pdf(date of access: 22.01.2019). - Title from screen.

\section{REFERENCES}

1. Biryukov S.V., Omelichkin O.V. Sovremennye mify Zapada o Rossii [Current Western Myths About Russia]. Vestnik Volgogradskogo gosudarstvennogo universiteta. Seriya 4. Istoriya. Regionovedenie. Mezhdunarodnye otnosheniya [Science Journal of Volgograd State University. History. Area Studies. International Relations], 2018, vol. 23, no. 6, pp. 185196. DOI: https://doi.org/10.15688/jvolsu4.2018.6.15.

2. Brilev S.B. Zabytye soyuzniki vo Vtoroy mirovoy voyne [Forgotten Allies in World War II]. Moscow, OLMA Media Grupp Publ., 2013. 712 p.

3. Broka P. Chelovechestvo - odin vid ili neskolko? [Is Human Race One Species or Several?]. Pravda-TV.ru, 2010, April 22. URL: http://www.pravdatv.ru/2010/04/22/3626 (accessed 21 January 2019).

4. Galeano E. Vskrytye veny Latinskoy Ameriky [Open Veins of Latin America]. Moscow, Progress Publ., 1986.398 p. 
5. Galich M. Istoriya dokolumbovykh tsivilizatsiy [History of Pre-Columbian Civilizations]. Moscow, Mysl Publ., 1990. 407 p.

6. Zubov A.A. Biologo-antropologicheskaya kharakteristika korennogo doevropeyskogo naseleniya Ameriki [Biological and Anthropological Characteristics of the Native Population of Pre-European America]. Istomin A.A., ed. Naselenie Novogo Sveta: problemy formirovaniya i sotsiokulturnogo razvitiya: sb. st. [Population of the New World: Problems of Formation and Socio-Cultural Development. Collected Articles]. Moscow, IEA RAN, 1999, pp. 11-66.

7. Kerzhakov B. «Dopodlinnye lyudi» charrua [The "Genuine People" Charruas]. Neobychnaya istoriya, 2014, January 28. URL: http://nethistory.su/ blog/43208728468/«Dopodlinnyie-lyudi»-charrua (accessed 21 January 2019).

8. Kolobashkin N.F. Urugvay: istoricheskiy ocherk [Uruguay. Historical Sketch]. Volskiy V.V., ed. Latinskaya Amerika: Entsiklopedicheskiy spravochnik. V 2 t. T. 2 [Encyclopedic Handbook of Latin America. In 2 Vols. Vol. 2]. Moscow, Sovetskaya Entsiklopediya Publ., 1982, pp. 506-508.

9. Proklyatie poslednego shamana charrua [The Curse of the Last Charrua Shaman]. Repin.info, 2009, August 20. URL: http://repin.info/taynye-znaniya/ proklyatie-poslednego-shamana-charrua (accessed 21 January 2019).

10. Stingl M. Indeitsy bez tomagavkov [Indians Without Tomahawks]. Moscow, Progress Publ., 1984. $454 \mathrm{p}$.

11. Charrua. Vvedenskiy B.A., ed. Bolshaya sovetskaya entsiklopediya. V 51 t. T. 47 [Great Soviet Encyclopedia. In 51 Vols. Vol. 47]. Moscow, BSE, 1957, p. 53.

12. Anghiera P.M. d'. Décadas del nuevo mundo. Buenos Aires, MAXTOR, 2012.675 p.

13. Arce Asenjo D. L'Uruguay, une nation d'extrême-occident au miroir de son histoire indienne. Paris, L'Harmattan, 2018. 394 p.

14. Arce Asenjo D. Nuevos datos sobre el destino de Tacuavé y de la hija de Micaela Guyunusa. Romero Gorski S., ed. Anuario de Antropologia Social y Cultural en Uruguay 2007. Montevideo, Universidad de la República, Facultad de Humanidades y Ciencias de la Educación, 2007, pp. 51-71. URL: http:// www.academia.edu/1105620/Nuevos_datos_sobre_el destino_de_Tacuavé_y_la_hija_de_Guyunusa (accessed 22 January 2019).

15. Azara F. de. Descripcion e historia del Paraguay y el Rio de la Plata. En 2 vols. Vol. 2. Madrid, Imprenta de Sanchiz, 1847. 286 p. URL: https:/ /books.google.ru/books?id=L3g1 AAAAIAAJ\&dq (accessed 23 January 2019).

16. Azara F. de. Voyage dans l'Amérique méridionale. En 4 vols. Vol. 2. Paris, Dentu, 1809. 562 p.
URL: https://books.google.ru/books ?id=zANCAAAA cAAJ\&dq (accessed 23 January 2019).

17. Barco Centenera M. del. Argentina y conquista del Rio de la Plata, con otros acaecimientos de los reynos del Peru, Tucuman, y estado del Brasil. Lisboa, Pedro Crasbeeck, 1602. 460 p. URL: https://books.google.ru/books?id=1 tJV AAAAcAAJ\&dq (accessed 23 January 2019).

18. Becker I.I.B. Os indios Charrua e Minuano na antiga banda oriental do Uruguai. São Leopoldo, RS, Brasil, Editora Unisinos, 2002. 248 p.

19. Bertuch F.J. Allgemeine geographische Ephemeriden. Weimar, Verlage des landes-Industrie comptoirs, 1809. 530 S. URL: https://books.google.de/ books?id=Ad4BAAAAYAAJ\&dq (accessed 23 January 2019).

20. Bracco D. Charrúas, Guenoas y Guaranies: Interacción y Destruccion: Indígenas en el Río de la Plata. Montevideo, Linardi y Risso, 2004. 398 p.

21. Bracco D. Con las armas en la mano: Charrúas, Guenoa-Minuanos y Guaranies. Montevideo, Planeta, 2013. 224 p.

22. Bracco D. Los guenoa minuanos misioneros. Memoria Americana. Cuadernos de Etnohistoria, 2016, no. 24-1, pp. 33-54. URL: http://www.scielo.org.ar/ $\mathrm{pdf} / \mathrm{memoam} / \mathrm{n} 24-1 / \mathrm{n} 24-1 \mathrm{a} 03 . p d f($ accessed 20 January 2019).

23. Charrúa. Castellano - La Página del Idioma Español. URL: http://www.elcastellano.org/palabra/ charrúa (accessed 22 January 2019).

24. Cordero S. Los charrúas: síntesis etnográfica y arqueológica del Uruguay. Montevideo, Editorial "Mentor", 1960. 322 p.

25. Figueira J.H. Los primitivos habitantes del Uruguay. Montevideo, Dornaleche y Reyes, 1892. 44 p.

26. Fiorotto D.T. Investigan los orígenes de una extraña lengua indígena. La Nación, 2005, July 1. URL: https://www.lanacion.com.ar/717592-investigan-losorigenes-de-una-extrana-lengua-indigena (accessed 22 January 2019).

27. Greenberg J.H. Language in the Americas. Stanford, Stanford University Press, 1987. 438 p.

28. Hervás L. Catálogo de las lenguas de las naciones conocidas, y numeracion, division, y clases de estas segun la diversidad de sus idiomas y dialectos. En 6 vols. Vol. 1. Madrid, En la imprenta de la Administracion del Real Arbitrio de Beneficencia, 1800. 396 p. URL: https://books.google.ru/books?id= 8vA3 GAo3S8kC\&hl (accessed 23 January 2019).

29. Los charrúas que no son charrúas. Taringa! 2015, October 21. URL: https://www.taringa.net/post/ info/19024456/Los-charruas-que-no-son-charruas. html (accessed 22 January 2019).

30. Lothrop S.K. Indians of the Paraná Delta and La Plata Littoral. Steward J.H., ed. Handbook of South American Indians. In 7 Vols. Vol. 1. The Marginal 
Tribes. Washington, D. C., Government Printing Office, 1946, pp. 177-190.

31. Loukotka Č., Wilbert J. Classification of South American Indian languages. Los Angeles, Latin American Studies Center, University of California, $1968.453 \mathrm{p}$.

32. Maruca Sosa R. La nación charrúa. Montevideo, Editorial "Letras", 1957.316 p.

33. Orbigny A.D. d'. L'homme americain (de l'Amérique méridionale). En 2 vols. Vol. 2. Paris, Pitois-Levrault et C., 1839. 372 p. URL: https://books. google.ru/books?id=-CAOAAAAQAAJ\&hl (accessed 23 January 2019).

34. Moguer D.G. de. Relación é derrotero de Diego Garcia que salió de la Coruna en 15 de enero de 1526, en el Mar Océano, é llegó en 27 al Rio Paraná, donde navegó muchas leguas tierra adentro la armada de Sebastian Caboto, etc., 1527. Medina J.T., comp. Colección de Documentos inéditos para la historia de Chile: desde el Viaje de Magallanes hasta la Batalla de Maipo: 1518-1818. En 30 vols. Vol. 3. Santiago de Chile, Imprenta Ercilla, 1889, pp. 40-48. URL: https://archive.org/details/raha_103066/page/n5 (accessed 23 January 2019).

35. Rivet P. Los últimos charrúas. Montevideo, Ediciones de la Plaza, 1996. 88 p.

36. Rosa J.J. da. Historiografía lingüística del Río de la Plata: las lenguas indígenas de la Banda Oriental. Boletín de Filología, 2013, vol. 48, no. 2, pp. 131-171. URL: https://scielo.conicyt.cl/pdf/bfilol/v48n2/ art_07.pdf(accessed 20 January 2019).

37. Rossi J.J. Los charrúas. Buenos Aires, Galerna, Búsqueda de Ayllu, 2002. 126 p.

38. Sans M., Figueiro G., Sanguinetti C. et al. The "Last Charrúa Indian" (Uruguay): Analysis of the Remains of Chief Vaimaca Perú. Nature Precedings, 2010, May 4. 14 p. URL: http://precedings.nature.com/ documents/4415/version/1/files/npre20104415-1.pdf (accessed 22 January 2019).

39. Schmidel U. Viaje al Río de la Plata (15341554). Buenos Aires, Cabaut y Cia, 1903. 499 p. URL: http://www.cervantesvirtual.com/obra-visor/viaje-al- rio-de-la-plata-1534-1554/html/ (accessed 23 January 2019).

40. Schmidt W. Die Sprachfamilien und Sprachenkreise der Erde. Heildelberg, H. Buske, 1926. $595 \mathrm{~S}$.

41. Sepp A., Behme A. An Account of a Voyage from Spain to Paraquaria. Translated from the High Dutch Original, Printed at Nurenberg, 1697. Churchill A., Churchill Jh., comp. A Collection of Voyages and Travels, Some Now First Printed from Original Manuscripts, Others Now First Published in English. In 6 Vols. Vol. 4. London, Assignment from Messrs. Churchill, 1732, pp. 596-622. URL: https: //books.google.ru/books?id=jORWAAAAcAAJ\&dq (accessed 23 January 2019).

42. Serrano A. The Charrua. Handbook of South American Indians. Vol. 1. Washington, D.C., 1946, pp. 191-196.

43. Sušnik B. Los aborígenes del Paraguay: Etnología del Chaco Boreal y su perifería, siglos XVI y XVII. Asunción, Museo Etnográfico Andrés Barbero, 1978.154 p.

44. Szilágyi Chebi M. E. Los charrúas en la memoria nacional de Uruguay. Acta Hispanica, 2015, vol. 20, pp. 105-120. URL: https://www.academia.edu/ 23457388/Los charrúas en la memoria nacional de_Uruguay (accessed 28 November 2019).

45. Techo N. del. Historia provinciae Paraquariae Societatis Jesv. Leodii, Ex officina typog. J. M. Hovii, 1673. 390 p. URL: https://books.google.ru/ books?id=76ZFAAAAcAAJ\&hl (accessed 23 January 2019).

46. Vidart D. El mundo de los charrúas. Montevideo, Ediciones de la Banda Oriental, 1996. $139 \mathrm{p}$.

47. Viegas Barros J.P. Misia jalaná: Una frase Charrúa a la luz de los nuevos datos de la lengua Chaná. Cuadernos de Etnolingüistica. Serie Notas, 2009 (nov.), no. 1.3 p. URL: http://etnolinguistica. wdfiles.com/local—files/nota:1/cadernos_notas_n1. pdf(accessed 22 January 2019).

\section{Information About the Author}

Timur V. Nelin, Candidate of Sciences (History), Associate Professor, Department of International Relations, Political Science and Area Studies, Volgograd State University, Prosp. Universitetsky, 100, 400062 Volgograd, Russian Federation, nelin@volsu.ru, https://orcid.org/0000-0002-7550-7426

\section{Информация об авторе}

Тимур Владимирович Нелин, кандидат исторических наук, доцент кафедры международных отношений, политологии и регионоведения, Волгоградский государственный университет, просп. Университетский, 100, 400062 г. Волгоград, Российская Федерация, nelin@volsu.ru, https://orcid.org/0000-0002-7550-7426 